\title{
Virulence Factors as Targets for Anticryptococcal Therapy
}

\author{
Renata V. D. M. Azevedo ${ }^{1, *}$, Juliana Rizzo ${ }^{2,3}$ and Marcio L. Rodrigues ${ }^{1,2}$ \\ 1 Fundação Oswaldo Cruz-Fiocruz, Centro de Desenvolvimento Tecnológico em Saúde (CDTS), \\ 21040-361 Rio de Janeiro, Brazil; marciolr@cdts.fiocruz.br \\ 2 Instituto de Microbiologia Paulo de Góes (IMPG), Universidade Federal do Rio de Janeiro, \\ 21941-902 Rio de Janeiro, Brazil; juju.rizzo@gmail.com \\ 3 Instituto de Bioquímica Médica (IBqM), Universidade Federal do Rio de Janeiro, \\ 21941-902 Rio de Janeiro, Brazil \\ * Correspondence: razevedo@cdts.fiocruz.br; Tel.: +55-21-9996-77962
}

Academic Editor: Maurizio Del Poeta

Received: 14 October 2016; Accepted: 25 November 2016; Published: 30 November 2016

\begin{abstract}
The global mortality due to cryptococcosis caused by Cryptococcus neoformans or C. gattii is unacceptably high. Currently available therapies are decades old and may be impacted by drug resistance. Therefore, the need for more effective antifungal drugs for cryptococcosis is evident. A number of Cryptococcus virulence factors have been studied in detail, providing crucial information about the fungal biology and putative molecular targets for antifungals. This review focuses on the use of well-described virulence factors of Cryptococcus as potential anticryptococcal agents.
\end{abstract}

Keywords: C. neoformans; cryptococcosis; virulence factors; anticryptococcal targets

\section{Introduction}

\subsection{The Need for Antifungal Drugs}

The number of invasive fungal infections has increased during the last few decades. About 1.2 billion people worldwide are estimated to suffer from fungal diseases [1,2] and the mortality rates for invasive infections are inadmissibly high [1]. In Brazil, a recent study estimated that serious fungal diseases affect more than 3.8 million people [3]. It is now clear that the number of deaths caused by fungal infections is similar to those produced by either tuberculosis [4] or malaria [5].

The great majority of reported fungal related deaths result from infections by four genera of fungi: Aspergillus, Candida, Cryptococcus, and Pneumocystis [1,6]. The limiting factors in the treatment of fungal infections comprise late diagnosis, high cost, and also drug-related issues, which include limited routes of administration, high toxicity, reduced spectrum of activity, unfavorable interactions, resistance, and reduced bioavailability in target tissues $[7,8]$.

Despite the increasing necessity for new antifungals, currently available drugs are limited in number [9] and not many are in preclinical development [7,10,11]. The long timeline required for drug development has stimulated drug-repositioning approaches. Sertraline, the most frequently prescribed antidepressant, is in clinical trial for cryptococcosis [12,13]. The drug has demonstrated in vivo antifungal activity in experimental cryptococcosis when administered either alone or synergistically with fluconazole [12]. Moreover, sertraline treatment prevented paradoxical cryptococcal immune reconstitution inflammatory syndrome (CM-IRIS) and relapse [14].

\subsection{Cryptococcosis: A Systemic Fungal Infection with Alarming Mortality Indices}

C. neoformans and C. gattii are encapsulated yeast-like pathogens causing human and animal cryptococcosis. Humans are exposed to Cryptococcus by inhalation of environmental infectious 
propagules $[15,16]$. Cryptococcosis has a worldwide distribution and is predominantly associated with immunocompromised individuals [17], although immunocompetent hosts can also acquire the disease [18]. Usually, the infection is asymptomatic and restricted to the lungs in individuals without impaired immunity. However, in immunocompromised patients the yeast cells can widely disseminate to most organs and commonly cause pneumonia and meningoencephalitis [19]. Human cryptococcosis became a global health problem in the 1980s in concomitance with the AIDS epidemics [17,19]. Cryptococcal disease is the second leading cause of mortality in HIV patients [19].

\subsection{Potential Targets for Development of Novel Anticryptococcal Agents}

The emergence of multi-resistant microbes points to the need of new strategies to develop novel antifungal therapies. An alternative approach to conventional antimicrobial therapy is to target virulence factors required to cause host damage and disease. As reviewed by Clatworthy and colleagues [20], this approach has several potential advantages, including expanding the repertoire of microbial targets, preserving the host endogenous microbiome, and exerting less selective pressure, which may result in decreased resistance. A number of $C$. neoformans virulence factors have been studied in detail and molecularly characterized. The main virulence-related molecules include capsular polysaccharides, melanin, and secreted enzymes [21-25]. Below, we describe C. neoformans virulence factors showing potential as targets for the development of novel antifungal drugs.

\subsubsection{Capsule Components}

One of the most important features of Cryptococcus is its outermost polysaccharide capsule, which protects the fungal cell from an array of host defense mechanisms [26,27]. The importance of the capsule for virulence is clear, since acapsular mutants are clearly less virulent than wild type strains [28,29]. The molecular composition of the polysaccharide capsule includes glucuronoxylomannan (GXM) and glucuronoxylomannogalactan (GXMGal), which assume a complex spatial conformation [30].

Despite the poor immunogenicity of capsular polysaccharides, monoclonal antibodies $(\mathrm{mAb})$ against capsule components were successfully generated through the use of conjugate antigens $[31,32]$. Some of the capsule mAbs were shown to bind all C. neoformans serotypes, with consequent activation of the complement pathway and enhancement of the antifungal activity of immune cells [32]. Passive administration of GXM-binding mAbs prolonged survival of lethally infected mice [33]. However, administration of IgG3 enhanced the infection and shortened the lives of immunocompetent mice [34] and also of CD4- and C5-deficient animals [33,34]. Phase I tests with the GXM-binding mAb 18B7 revealed undesired effects at doses higher than $1 \mathrm{mg} / \mathrm{kg}$ [35].

Alternative strategies to control cryptococcal virulence could involve the enzymes required for capsule biosynthesis. Several glycosyltransferases are necessary for synthesis and assembly of GXM and GXMGal backbones [36].

The first capsule-related enzyme identified was cryptococcal xylosyltransferase 1 (Cxt1), a large transmembrane protein which mediates $\beta$-1,2-linkage formation by transferring xylose from a donor nucleotide to a reducing mannose acceptor $[37,38]$. Deletion of the corresponding gene affected fungal survival in the lungs of infected mice, indicating that the presence of xylosyle linkages in the capsule is important for host-pathogen interactions [39]. Genome analysis revealed the existence of five homologs of CXT1 in C. neoformans and 34 orthologs in other fungi, but none in other organisms [37]. Xylosyl transfer in $C$. neoformans also requires xylosyltransferase 2 (Cxt2), which also mediates $\beta-1,2$-xylose addition to mannosyl units [40]. However, contrary to the closely related Cxt1, little is known regarding the functional role of Cxt2. Although xylosyltransferase activity is present in many organisms, including plants and animals [41,42], Cxt1 and its homologous counterparts comprise a novel family of glycosyltransferases which is unique to the fungal kingdom and, therefore, represent attractive targets for selective and effective therapeutic agents [37].

Reilly and colleagues have recently described that the addition of xylose-phosphate (Xyl-P) to mannose-containing substrates, generating xylosylphosphomannose (Xyl-P-Man), also occurs in 
C. neoformans [40]. The enzyme responsible for this activity was xylosylphosphotransferase 1 (Xpt1), which does not resemble any other known xylosyltransferase. So far, this enzymatic activity has only been observed in $C$. neoformans and its biological significance is still under investigation. A mutant strain $(x p t 1 \Delta)$ revealed that the loss of Xpt1 did not influence the ability of $C$. neoformans to colonize mice lungs, express virulence factors, and grow under stress conditions [43], although one cannot discard its role in virulence before other infection models can be assessed. Interestingly, no capsular polysaccharides seem to contain the Xyl-P-Man moiety, suggesting that this enzyme may be involved in other metabolic processes, such as $O$-glycosylation of proteins [43]. The exclusive occurrence in C. neoformans suggests that future studies aiming at elucidating the functions of Xpt1 may produce important information on unusual glycans and their biosynthetic pathways.

Enzymes involved in mannose incorporation to capsular polysaccharides were also studied in detail [44,45]. Mannosyl units represent more than $50 \%$ of the capsule mass [46]. This carbohydrate unit is coupled with GDP (Guanosine diphosphate) for utilization in glycan biosynthetic reactions [46]. Most GDP-mannose donors are used within the lumen of Golgi complex, thus requiring specific transmembrane transporters to leave the cytosol and reach this organelle. In C. neoformans, there are two GDP-mannose transporters, Gmt1 and Gmt2, which are similar at the amino acid level but distinct in cellular function [44]. While both factors are able to promote GDP-mannose transport in vitro and to effectively complement its homolog in S. cerevisiae, the phenotypic outcome of C. neoformans single mutations revealed significant differences in cellular growth, colony morphology, protein glycosylation, and capsule structure [44,45]. In addition, transcription analysis revealed that they are not coordinately regulated, providing supporting evidence that their biological roles are distinct, at least to some extent [44]. Further investigation with a double mutant strain lacking Gmt1 and Gmt2 revealed that capsule biosynthesis, protein glycosylation processes, and virulence were severely affected [45]. GDP-mannose transporters have also been identified in other fungi [47-51], plants [52,53], and the protozoan parasite Leishmania donovani [54]. However, humans and other mammalian hosts of C. neoformans do not perform mannosylation reactions inside the Golgi lumen and therefore do not express any form of GDP-mannose transporters, indicating that these proteins may be potential targets for antifungal chemotherapy [45].

Mannosyltransferases constitute another class of enzymes involved in mannose incorporation into the capsule [55]. In C. neoformans, Cmt1 is the enzyme generating the $\alpha-1,3$-linked backbone of the GXM polymer [56]. Deletion of CMT1 abolished the enzymatic activity but did not prevent capsule formation or virulence in an infected mouse model, suggesting that other factors might also participate in GXM biosynthesis, compensating for the loss of $\mathrm{Cmt1}$ [56]. A possible candidate is the protein encoded by CAP64, which was found to interact with $\mathrm{Cmt}$ [56]. Interestingly, the search for similar proteins in non-redundant databases, including the model yeast S. cerevisiae, yielded a Cmt1 homolog, the predicted product of $C$. neoformans CAP59 gene [56]. Additional homologs in other species may also exist, as suggested in the dimorphic fungus Paracoccidioides brasiliensis [57]. Finally, mammals and other animal hosts lack $\mathrm{Cmt1}$, which seems to be found exclusively in fungal species. Thus, despite the non-conclusive data, $\mathrm{Cmt} 1$ and associated enzymes should not be ruled out as putative targets for therapeutic intervention.

Recently, through a proteomics-based approach, a hydrolytic enzyme involved in capsule assembly was identified as lactonohydrolase (Lhc1) [58]. This secreted enzyme is believed to affect the tertiary structure of the capsule, since mutants lacking the gene encoding Lhc1 exhibited larger capsules with altered branching, density, and solvation [58]. Most importantly, the $l h c 1 \Delta$ strain showed increased antibody opsonization and decreased survival when incubated with macrophage-like cells, as well as reduced virulence in mice [58]. Finally, lacnotohydrolases are commonly found in plants, fungi, and bacteria, but never have been described in humans (the closer relatives are the serum paraoxonases) [59], which makes this enzyme an interesting target for antifungal compounds. 


\subsubsection{Melanin}

Melanin contributes to $C$. neoformans virulence by increasing its survival in macrophages and by protecting the fungus against host effector mechanisms, such as production of oxidants and microbicidal peptides [60]. Melanized fungal cells have lower susceptibility to amphotericin B and caspofugin, interfering with the effectiveness of the treatment for cryptococcosis [61].

Melanin is an attractive target for therapeutic intervention. Compounds binding the pigment with high-affinity have been identified and tested for their ability to affect cellular growth, viability, pigmentation, and capacity to prolong survival of infected mice $[62,63]$. One of these compounds, the anti-psychotic drug trifluoperazine, effectively killed melanized cells in vitro and in vivo $[63,64]$. Another example is the herbicide glyphosate, which inhibited melanin production and prolonged survival of lethally infected mice [65]. The anti-parasitic drug chloroquine, on the other hand, was able to bind melanin and promote toxic activity on human melanoma cells [66], but produced no inhibitory outcome on fungal cells [63]. Despite these promising data, melanin-binding drugs have not been tested in humans.

Melanin can also be targeted by binding peptides or specific antibodies [67]. When tested in lethally infected mice, mAbs to melanin prolonged survival of infected mice and reduced fungal burden in different organs [67], suggesting that passive immunization with melanin mAbs could have therapeutic potential. Additionally, since this pigment is present in many fungal species, mAbs could be used to treat diseases other than cryptococcosis.

In C. neoformans, the pigment melanin is synthesized by the enzyme laccase, a glycosylated copper-containing protein with the ability to oxidize diphenolic substrates acquired extracellularly [68]. In addition to melanin, laccase is able to generate other products, such as dopamine $O$-quinone, which is spontaneously converted to dopaminochrome, a cytotoxic compound in the brain [69]. Moreover, this enzyme possesses iron oxidase activity, which was shown to reduce hydroxyl radical formation in macrophages [70]. $L A C 1$ and $L A C 2$ are $C$. neoformans genes encoding laccases, which are positioned $8 \mathrm{~kb}$ apart from each other [71]. The corresponding proteins differ in subcellular location, with Lac1 being predominantly found on the cell wall and Lac2 in the cytoplasm [71,72]. Deletion mutants of both genes showed reduced melanin production, although $L A C 1$ seems to play a major role in pigmentation [71]. The absence of $L A C 1$ also resulted in diminished virulence and prolonged survival in mice [73], which was not replicated in LAC2 deficient strains [74]. LAC1's predominant role in infection was supported by the observation that lac1 $\Delta$ mutants had decreased ability to escape the oxidative attack of primary macrophages. In this model, lac $1 \Delta$ mutants were affected more severely (i.e., higher killing index) than lac $2 \Delta$ cells. An important additive role played by both factors was suggested based on the greater response achieved in lac1 $\Delta l a c 2 \Delta$ double mutants [71]. Given the importance of laccase for melanin production and other virulence mechanisms, combined with the fact that similar enzymes are absent in the human host, this enzyme is an obvious target for antifungal therapies.

\subsubsection{Extracellular Enzymes}

Secretion of extracellular enzymes is crucial for C. neoformans virulence [75]. Extracellular hydrolases are necessary for obtaining essential nutrients from the surrounding environment of C. neoformans. Therefore, it is expected that this fungus will export a number of enzymes able to degrade proteins, lipids, sugars, and nucleic acids into smaller subunits or secondary metabolites to be internalized by the fungal cell. Some of these enzymes are required for virulence by mediating tissue invasion, colonization, or modulation of the immune response [76]. Others, including proteases and DNAses, have still obscure functions and will not be included in the discussion of this topic.

C. neoformans urease is required for urea metabolism in the environment, providing substrates to be used in different fungal metabolic pathways [77]. The enzyme is also a major virulence factor [77]. Urease contributes to the dissemination of fungal cells from the lung to the central nervous system, enhancing pathogen sequestration within microcapillary beds, thus aiding blood-brain barrier crossing [78]. Importantly, a urease knockout strain (ure1) was hypovirulent, yielding lower 
cryptococcal burden in the brain and reduced mortality rates of lethally infected mice [78]. Considering that urease is naturally absent in humans, pharmacological inhibition or antibody therapies have been proposed as useful strategies to protect the brain against cryptococcal meningitis [77,79].

C. neoformans also produces extracellular phosphatases, which influence adhesion to epithelial cells and promote invasion of host tissues [80]. Apparently most of the C. neoformans phosphatase activity comes from the acidic phosphatase Aph1 [81]. The enzyme is transported to the fungal cell periphery and vacuoles via endosome-like structures [81]. Survival assays with the wax worm Galleria mellonella and mice showed that animals infected with the aph1 deletion mutant lived longer than those infected with the wild type strain (WT), demonstrating that Aph1 contributes to cryptococcal virulence [81]. It is believed that this enzyme acts by recycling phosphate from other molecules inside the vacuoles, as well as by acquiring phosphates from the extracellular environment [81]. Sequence analysis indicates that Aph1 belongs to the group of histidine acid phosphatases and is most similar to fungal phytases (phytic acid-degrading enzymes) [82]. Interestingly, while the catalytic domain seems to be conserved, the proton donor and substrate-binding residues vary considerably among these enzymes, opening room for site-specific drug inhibition strategies [82].

Extracellular phospholipases $B$ and $C$ of $C$. neoformans are also important mediators of pathogenesis. Phospholipase B, encoded by the PLB1 gene, promotes the growth of cryptococcal cells within macrophages [83-85]. The enzyme is also required for interstitial pulmonary infection and further dissemination to lymph nodes and blood [86]. Under temperature stress, secretion of Plb1 decreases, resulting in enzyme accumulation on the cell wall [87]. At this cellular site, the enzyme appears to regulate wall integrity [87].

Phospholipases B have been described in several eukaryotes, including yeast and mammals [88]. However, $\mathrm{Plb}$ from pathogenic fungi seems to have unique properties, making them potential targets for antifungal drug development [89]. Many compounds have been tested against the fungal Plb. Some commercially available compounds displayed antifungal activity and were selective for $C$. neoformans $\mathrm{Plb1}$, showing no inhibition of the mammalian phospholipase [90]. A bis-pyridinium compound with broad-spectrum fungicidal activity, while non-toxic to mammalian cells, was recently described $[89,90]$.

Phospholipase C is encoded by two genes, namely PLC1 and PLC2 [91]. In contrast to PLC2, $P L C 1$ seems to be crucial for fungal growth and morphology, cell wall integrity, and antifungal drug resistance [91]. Importantly, the functions of PLC1 are also connected to other virulence related phenotypes, such as secretion of phospholipase B, melanin production, and growth at $37^{\circ} \mathrm{C}$ [91]. Plc1 biochemical functions include generation of inositol trisphosphate (IP3) as a substrate for Arg1 kinase, which is fundamental for fungal virulence [92]. C. neoformans Plc1 differs from the mammalian homolog Plc- $\delta$ in many aspects, although the fungal and mammalian enzymes share $32 \%$ of similarity. The mammalian enzyme possesses both the EF hand regulatory domain and the pleckstrin homology (PH) membrane binding domain that are absent in the fungal enzyme, indicating discrepancies in their mechanism of action [90]. Differences in the N-terminal length between the fungal and the mammalian enzymes were also observed $[93,94]$. Moreover, yeast Plc is predicted to be basic whereas the mammalian enzyme is an acidic protein. These structural differences associated with the role of Plc1 as a virulence factor reinforces phospholipase $C$ as a potential antifungal drug target [93].

Cryptococcal cells secrete superoxide dismutases (Sods), enzymes that convert superoxide to hydrogen peroxide and oxygen, thus reducing the harmful load of oxidants in the extracellular milieu [95]. It has been reported that Sods may assist fungal growth inside macrophages by buffering superoxide molecules, which are released as part of the immune response [96]. At least two Sods are produced by C. neoformans, namely Sod1 and Sod2 [97-99]. Single and double knockout mutants showed that both are important for virulence in a mouse model of cryptococcosis. While Sod1 primarily acts by mediating resistance to superoxide attack by neutrophils, Sod2 protects fungal cells from high concentration superoxide anions that would otherwise limit growth [98,99]. Interestingly, Sod production is increased at higher temperatures, such as that inside the human host $[100,101]$. Despite the presence of human homologs of cryptococcal Sods $[97,99]$, these enzymes could still be 
considered interesting drug targets if fungal-specific inhibitors are discovered. In fact, little variation was found in Sod2 proteins among C. neoformans variants, indicating that drugs affecting this potential target could be useful against all cryptococcal serotypes [101].

\subsubsection{Regulators of Unconventional Secretory Pathways}

As previously mentioned, the pathogenesis of $C$. neoformans is incontestably dependent on secretory mechanisms, since many virulence factors are surface-associated or extracellular [102]. The conventional pathway by which eukaryotic cells secrete molecules to the cell surface requires the traffic of proteins containing signal peptides from the endoplasmatic reticulum (ER) to the Golgi [103]. The remarkable lack of signal peptides in most of the well-characterized virulence factors of $C$. neoformans suggests that unconventional secretion pathways are involved directly with cryptococcal pathogenesis.

Different regulators of unconventional secretion in C. neoformans have been studied, including Golgi reassembly and stacking protein (Grasp), the eukaryotic sucrose non-fermenting protein 7 (Snf7), and the putative aminophospholipid translocase (Apt1 flippase) [104-106]. A C. neoformans Grasp mutant exhibited attenuated virulence in mice in comparison to wild type cells [104]. Deletion of GRASP also resulted in reduced polysaccharide secretion, decreased capsular dimensions, altered Golgi morphology, and efficient association to macrophages [104]. Likewise, $\mathrm{Xu}$ and colleagues demonstrated that grasp $\Delta$ mutant cells have reduced capsules and impaired hyphal growth [107]. Recently, biochemical and biophysical studies of C. neoformans Grasp in solution revealed the presence of intrinsically disordered regions (IDRs) in its structure. These regions can be crucial to understanding the cellular processes in which Grasp participates [108].

Similar to Grasp, the deletion of SNF7, the gene encoding a protein involved in multivesicular body (MVB) formation, affected crucial virulence determinants in both C. neoformans and C. gattii [106]. snf $7 \Delta$ mutants manifested pigmentation defects, reduced extracellular GXM, defective capsule formation, loss of virulence in a murine model of intranasal cryptococcal infection, and reduced survival in macrophages [106,109]. Finally, mutation of $C$. neoformans APT1 resulted in defective synthesis and vesicular export of GXM, diminished survival rates in the lungs of infected mice, ineffectiveness of brain colonization, and changes in the Golgi morphology [105]. Abnormal Golgi in apt1 $\Delta$ cells is probably due to defects in the control of membrane asymmetry, the primary function of the lipid flippases [105]. Deletion of CDC50, which encodes the $\beta$-subunit of a lipid flippase, affected fungal virulence and survival inside macrophages [110].

\subsubsection{Other Cryptococcal Targets}

The fungal glycosphingolipid glucosylceramide (GlcCer) is involved in a range of biological events in C. neoformans, including cell growth, lipid raft formation, immunogenicity, alkaline tolerance, and, ultimately, regulation of fungal virulence [111]. Although GlcCer is generally present in membranes, it accumulates on the cell wall [111,112]. Antibodies to C. neoformans GlcCer inhibited fungal growth in vitro [112] and prolonged the survival of lethally infected mice [113]. A C. neoformans mutant strain lacking GlcCer synthase (Gcs1) failed to grow in neutral/alkaline pHs that mimic the extracellular environment of the host during infection [114]. On the basis of the fact that human and fungal GlcCer are structurally different [115], drug library screenings targeting GlcCer synthesis were performed to identify GlcCer inhibitors. Two hydrazycins, BHBM and its derivative D0, interfered with GlcCer synthesis, impaired vesicular transport, and controlled animal cryptococcosis [116]. In this context, GlcCer is an already validated target for new antifungal drugs. 
Heat-shock proteins (Hsps) play important roles in various biological processes including transcription, translation, protein folding, and aggregation of proteins [117]. A recent study has demonstrated that targeting C. neoformans Hsp90 with radicicol (RAD) affected in vitro growth of planktonic cells of Cryptococcus and improved the in vitro effect of antifungal drugs, especially fluconazole [118]. The enhanced antifungal activity of fluconazole was also detected through in vivo, using Caenorhabditis elegans as a host [118]. The effects of RAD included reduced permeability of the plasma membrane and decreased capsular dimensions [118]. Antibody therapies targeting Hsp90 have been tested in the C. albicans model [119], reinforcing the potential role of this protein as a target for antibodies.

It has been demonstrated that the calcineurin pathway represents a key component on cell stress responses [120] and is involved in C. neoformans pathogenesis, due to its crucial role in determining fungal growth based upon the host's temperature $\left(37^{\circ} \mathrm{C}\right)$ [121]. Calcineurin mutants are unable to grow at elevated host temperatures and are not pathogenic in animal models of infection [122]. Therefore, the calcineurin pathway can be a potential therapeutic target for cryptococcosis. Studies utilizing the calcineurin inhibitors cyclosporine A (CsA) and tacrolimus (FK506), both immunosuppressants, revealed the potential of the calcineurin pathway to identify inhibitors of fungal growth $[121,123]$. Although it is challenging to use drugs inhibiting pathways highly conserved from human to yeast, such as the calcineurin pathway and Hsp90, even the presence of slightly structural differences in the drug binding site can be used to develop target specific inhibitors [124]. Previously, subtle structural differences allowed fungal specific calcineurin inhibitor analogs to be identified [125]. Additionally, in some other cases, such as the Hsp90 chaperone complex, co-factors can be used as a target for fungal specific inhibitors [124].

$\mathrm{N}$-myristoylation is an essential protein modification process catalyzed by the enzyme $\mathrm{N}$-myristoyltransferase (NMT), which relocates myristate from myristoyl-CoA to the $\mathrm{N}$-terminal glycine residue of a specific set of cellular proteins. In C. neoformans, a functional NMT is determinant for survival and dissemination inside the host [126,127]. The myristate analog 4-oxatetradecanoic acid was an effective NMT inhibitor associated with fungicidal effects in vitro [128]. Other NMT inhibitor compounds with putative fungicidal properties have been identified and may support the design of NMT-based therapies for cryptococcosis [129-131]. While $N$-myristoylation is abundant in protozoa, fungi, and mammals [132], peptide-binding studies revealed that substrates for NMTs are specific for each species. This observation indicates a great potential for development of species-specific inhibitors [132,133].

\section{Concluding Remarks}

This review highlights several aspects related to the identification of cryptococcal virulence factors that could be used as targets for the development of new drugs, as summarized in Figure 1. The identification of new molecular targets and therapeutic strategies to fight cryptococcal disease is not only important but also necessary to improve human survival rates, especially in immunocompromised individuals. Virulence factors and associated enzymatic pathways are obvious target choices, since their functions directly affect interaction with the host and the immune response. 


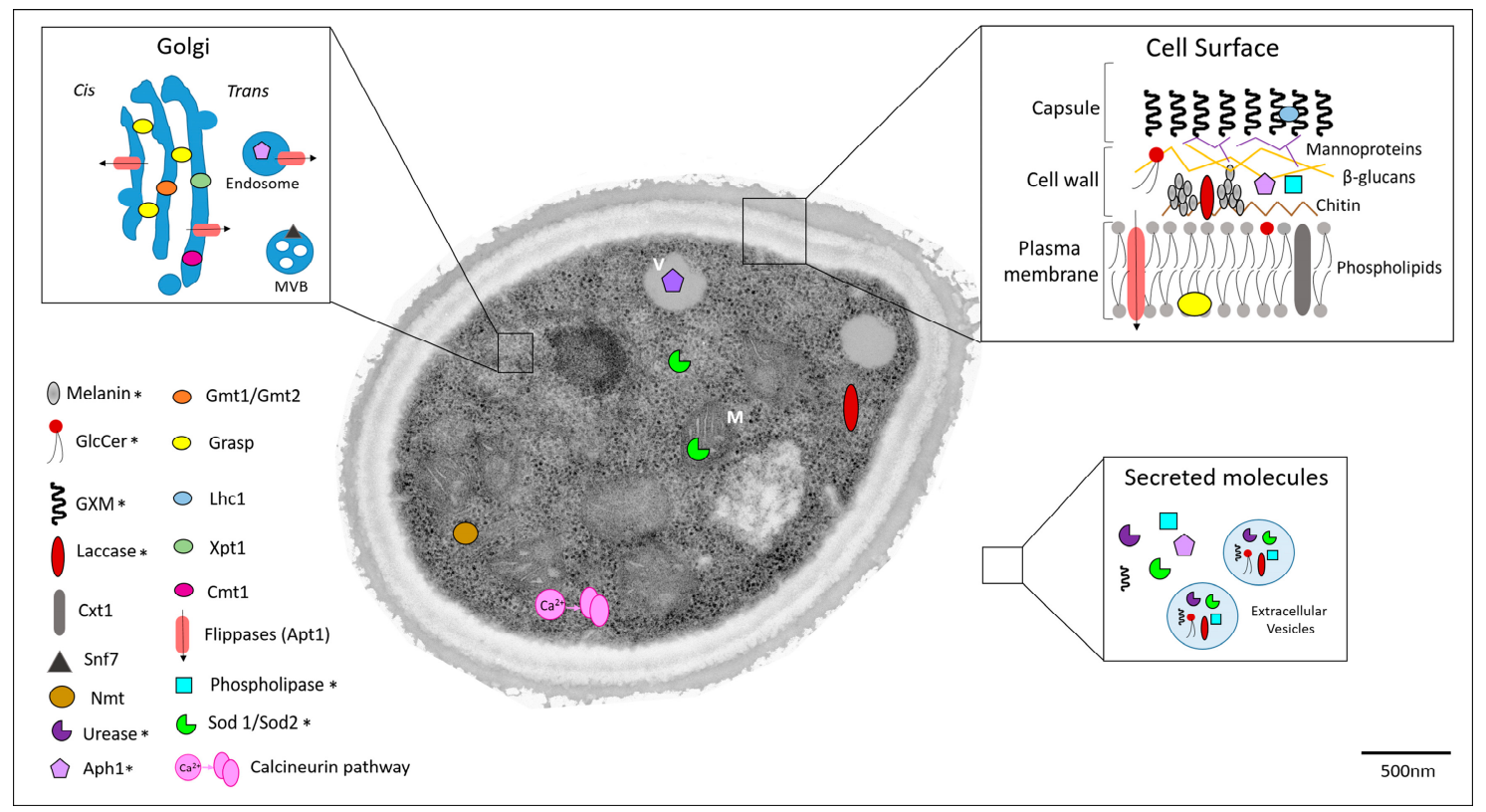

Figure 1. Cellular localization of potential targets for anticryptococcal therapy. Asterisks denote cellular targets that had their distribution confirmed by microscopic approaches. Other targets had their cellular distribution estimated according to their predicted or characterized functions. Cell surface, Golgi, and extracellular environment are highlighted. Secreted molecules are differentiated into soluble or extracellular-associated vesicles. M: mitochondria; V: vacuole; MVB: multivesicular bodies.

Acknowledgments: Renata V. D. M. Azevedo acknowledges support from Coordenação de Aperfeiçoamento de Pessoal de Nível Superior (Capes). Juliana Rizzo acknowledges support from Conselho Nacional de Desenvolvimento Científico e Tecnológico $(\mathrm{CNPq})$ and Fundação de Amparo à Pesquisa do Estado do Rio de Janeiro (FAPERJ). Marcio L. Rodrigues acknowledges support from the Instituto Nacional de Ciência e Tecnologia de Inovação em Doenças Negligenciadas (INCT-IDN, CNPq, grant number 573642/2008-7). Marcio L. Rodrigues is also supported by grants from the Brazilian agencies CNPq (grant numbers 443586/2014-4 and 300699/2013-1) and FAPERJ (grant numbers E-26/102.835/2012 and 210.918/2015) and is the recipient of a Pathfinder Award from the Wellcome Trust (UK, grant number WT104741MA).

Author Contributions: Renata Azevedo, Juliana Rizzo and Marcio Rodrigues discussed manuscript outline, wrote the text and prepared Figure 1.

Conflicts of Interest: The authors declare no conflict of interest.

\section{References}

1. Brown, G.D.; Denning, D.W.; Gow, N.A.R.; Levitz, S.M.; Netea, M.G.; White, T.C. Hidden killers: Human fungal infections. Sci. Transl. Med. 2012, 4, 165rv13. [CrossRef] [PubMed]

2. Vos, T.; Flaxman, A.D.; Naghavi, M.; Lozano, R.; Michaud, C.; Ezzati, M.; Shibuya, K.; Salomon, J.A.; Abdalla, S.; Aboyans, V.; et al. Years lived with disability (YLDs) for 1160 sequelae of 289 diseases and injuries 1990-2010: A systematic analysis for the Global Burden of Disease Study 2010. Lancet Lond. Engl. 2012, 380, 2163-2196. [CrossRef]

3. Giacomazzi, J.; Baethgen, L.; Carneiro, L.C.; Millington, M.A.; Denning, D.W.; Colombo, A.L.; Pasqualotto, A.C.; Association with the LIFE Program. The burden of serious human fungal infections in Brazil. Mycoses 2016, 59, 145-150. [CrossRef] [PubMed]

4. WHO। Tuberculosis. Available online: http://www.who.int/mediacentre/factsheets/fs104/en/ (accessed on 30 May 2016).

5. WHO I Malaria. Available online: http://www.who.int/mediacentre/factsheets/fs094/en/ (accessed on 30 May 2016).

6. Denning, D.W.; Bromley, M.J. Infectious Disease. How to bolster the antifungal pipeline. Science 2015, 347, 1414-1416. [CrossRef] [PubMed] 
7. Brown, G.D.; Denning, D.W.; Levitz, S.M. Tackling human fungal infections. Science 2012, 336, 647. [CrossRef] [PubMed]

8. Nóbrega, R.O.; Teixeira, A.P.; Oliveira, W.A.; Lima, E.O.; Lima, I.O. Investigation of the antifungal activity of carvacrol against strains of Cryptococcus neoformans. Pharm. Biol. 2016, 54, 2594-2596. [CrossRef] [PubMed]

9. Butts, A.; Krysan, D.J. Antifungal drug discovery: Something old and something new. PLoS Pathog. 2012, 8 , e1002870. [CrossRef] [PubMed]

10. Chong, C.R.; Sullivan, D.J. New uses for old drugs. Nature 2007, 448, 645-646. [CrossRef] [PubMed]

11. Butts, A.; DiDone, L.; Koselny, K.; Baxter, B.K.; Chabrier-Rosello, Y.; Wellington, M.; Krysan, D.J. A Repurposing approach identifies off-patent drugs with fungicidal cryptococcal activity, a common structural chemotype, and pharmacological properties relevant to the treatment of cryptococcosis. Eukaryot. Cell 2013, 12, 278-287. [CrossRef] [PubMed]

12. Zhai, B.; Wu, C.; Wang, L.; Sachs, M.S.; Lin, X. The antidepressant sertraline provides a promising therapeutic option for neurotropic cryptococcal infections. Antimicrob. Agents Chemother. 2012, 56, 3758-3766. [CrossRef] [PubMed]

13. De Treviño-Rangel, R.J.; Villanueva-Lozano, H.; Hernández-Rodríguez, P.; Martínez-Reséndez, M.F.; García-Juárez, J.; Rodríguez-Rocha, H.; González, G.M. Activity of sertraline against Cryptococcus neoformans: In vitro and in vivo assays. Med. Mycol. 2016, 54, 280-286. [CrossRef] [PubMed]

14. Rhein, J.; Morawski, B.M.; Hullsiek, K.H.; Nabeta, H.W.; Kiggundu, R.; Tugume, L.; Musubire, A.; Akampurira, A.; Smith, K.D.; Alhadab, A.; et al. Efficacy of adjunctive sertraline for the treatment of HIV-associated cryptococcal meningitis: An open-label dose-ranging study. Lancet Infect. Dis. 2016, 16, 809-818. [CrossRef]

15. Velagapudi, R.; Hsueh, Y.-P.; Geunes-Boyer, S.; Wright, J.R.; Heitman, J. Spores as infectious propagules of Cryptococcus neoformans. Infect. Immun. 2009, 77, 4345-4355. [CrossRef] [PubMed]

16. Chayakulkeeree, M.; Perfect, J.R. Cryptococcosis. Infect. Dis. Clin. N. Am. 2006, 20, 507-544. [CrossRef] [PubMed]

17. May, R.C.; Stone, N.R.H.; Wiesner, D.L.; Bicanic, T.; Nielsen, K. Cryptococcus: From environmental saprophyte to global pathogen. Nat. Rev. Microbiol. 2016, 14, 106-117. [CrossRef] [PubMed]

18. Maziarz, E.K.; Perfect, J.R. Cryptococcosis. Infect. Dis. Clin. N. Am. 2016, 30, 179-206. [CrossRef] [PubMed]

19. Park, B.J.; Wannemuehler, K.A.; Marston, B.J.; Govender, N.; Pappas, P.G.; Chiller, T.M. Estimation of the current global burden of cryptococcal meningitis among persons living with HIV/AIDS. AIDS Lond. Engl. 2009, 23, 525-530. [CrossRef] [PubMed]

20. Clatworthy, A.E.; Pierson, E.; Hung, D.T. Targeting virulence: A new paradigm for antimicrobial therapy. Nat. Chem. Biol. 2007, 3, 541-548. [CrossRef] [PubMed]

21. O'Meara, T.R.; Alspaugh, J.A. The Cryptococcus neoformans capsule: A sword and a shield. Clin. Microbiol. Rev. 2012, 25, 387-408. [CrossRef] [PubMed]

22. Rodrigues, M.L.; Alviano, C.S.; Travassos, L.R. Pathogenicity of Cryptococcus neoformans: Virulence factors and immunological mechanisms. Microbes Infect. Inst. Pasteur 1999, 1, 293-301. [CrossRef]

23. Williamson, P.R. Laccase and melanin in the pathogenesis of Cryptococcus neoformans. Front. Biosci. J. Virtual Libr. 1997, 2, e99-e107. [CrossRef]

24. Casadevall, A.; Rosas, A.L.; Nosanchuk, J.D. Melanin and virulence in Cryptococcus neoformans. Curr. Opin. Microbiol. 2000, 3, 354-358. [CrossRef]

25. Casadevall, A.; Perfect, R.J. Cryptococcus neoformans; ASM Press: Washington, DC, USA, 1998.

26. Zaragoza, O.; Rodrigues, M.L.; De Jesus, M.; Frases, S.; Dadachova, E.; Casadevall, A. The capsule of the fungal pathogen Cryptococcus neoformans. Adv. Appl. Microbiol. 2009, 68, 133-216. [PubMed]

27. Vecchiarelli, A.; Pericolini, E.; Gabrielli, E.; Kenno, S.; Perito, S.; Cenci, E.; Monari, C. Elucidating the immunological function of the Cryptococcus neoformans capsule. Future Microbiol. 2013, 8, 1107-1116. [CrossRef] [PubMed]

28. Chang, Y.C.; Kwon-Chung, K.J. Complementation of a capsule-deficient mutation of Cryptococcus neoformans restores its virulence. Mol. Cell. Biol. 1994, 14, 4912-4919. [CrossRef] [PubMed]

29. Fromtling, R.A.; Shadomy, H.J.; Jacobson, E.S. Decreased virulence in stable, acapsular mutants of Cryptococcus neoformans. Mycopathologia 1982, 79, 23-29. [CrossRef] [PubMed] 
30. Frases, S.; Pontes, B.; Nimrichter, L.; Viana, N.B.; Rodrigues, M.L.; Casadevall, A. Capsule of Cryptococcus neoformans grows by enlargement of polysaccharide molecules. Proc. Natl. Acad. Sci. USA 2009, 106, 1228-1233. [CrossRef] [PubMed]

31. Casadevall, A.; Mukherjee, J.; Devi, S.J.; Schneerson, R.; Robbins, J.B.; Scharff, M.D. Antibodies elicited by a Cryptococcus neoformans-tetanus toxoid conjugate vaccine have the same specificity as those elicited in infection. J. Infect. Dis. 1992, 165, 1086-1093. [CrossRef] [PubMed]

32. Casadevall, A.; Cleare, W.; Feldmesser, M.; Glatman-Freedman, A.; Goldman, D.L.; Kozel, T.R.; Lendvai, N.; Mukherjee, J.; Pirofski, L.A.; Rivera, J.; et al. Characterization of a murine monoclonal antibody to Cryptococcus neoformans polysaccharide that is a candidate for human therapeutic studies. Antimicrob. Agents Chemother. 1998, 42, 1437-1446. [PubMed]

33. Shapiro, S.; Beenhouwer, D.O.; Feldmesser, M.; Taborda, C.; Carroll, M.C.; Casadevall, A.; Scharff, M.D. Immunoglobulin $\mathrm{G}$ monoclonal antibodies to Cryptococcus neoformans protect mice deficient in complement component C3. Infect. Immun. 2002, 70, 2598-2604. [CrossRef] [PubMed]

34. Yuan, R.R.; Casadevall, A.; Oh, J.; Scharff, M.D. T cells cooperate with passive antibody to modify Cryptococcus neoformans infection in mice. Proc. Natl. Acad. Sci. USA 1997, 94, 2483-2488. [CrossRef] [PubMed]

35. Larsen, R.A.; Pappas, P.G.; Perfect, J.; Aberg, J.A.; Casadevall, A.; Cloud, G.A.; James, R.; Filler, S.; Dismukes, W.E. Phase I evaluation of the safety and pharmacokinetics of murine-derived anticryptococcal antibody $18 \mathrm{~B} 7$ in subjects with treated cryptococcal meningitis. Antimicrob. Agents Chemother. 2005, 49, 952-958. [CrossRef] [PubMed]

36. Doering, T.L. How sweet it is! Cell wall biogenesis and polysaccharide capsule formation in Cryptococcus neoformans. Annu. Rev. Microbiol. 2009, 63, 223-247. [CrossRef] [PubMed]

37. Klutts, J.S.; Levery, S.B.; Doering, T.L. A $\beta-1,2$-xylosyltransferase from Cryptococcus neoformans defines a new family of glycosyltransferases. J. Biol. Chem. 2007, 282, 17890-17899. [CrossRef] [PubMed]

38. Castle, S.A.; Owuor, E.A.; Thompson, S.H.; Garnsey, M.R.; Klutts, J.S.; Doering, T.L.; Levery, S.B. $\beta 1,2$-xylosyltransferase Cxt1p is solely responsible for xylose incorporation into Cryptococcus neoformans glycosphingolipids. Eukaryot. Cell 2008, 7, 1611-1615. [CrossRef] [PubMed]

39. Klutts, J.S.; Doering, T.L. Cryptococcal xylosyltransferase 1 (Cxt1p) from Cryptococcus neoformans plays a direct role in the synthesis of capsule polysaccharides. J. Biol. Chem. 2008, 283, 14327-14334. [CrossRef] [PubMed]

40. Reilly, M.C.; Levery, S.B.; Castle, S.A.; Klutts, J.S.; Doering, T.L. A novel xylosylphosphotransferase activity discovered in Cryptococcus neoformans. J. Biol. Chem. 2009, 284, 36118-36127. [CrossRef] [PubMed]

41. Bencúr, P.; Steinkellner, H.; Svoboda, B.; Mucha, J.; Strasser, R.; Kolarich, D.; Hann, S.; Köllensperger, G.; Glössl, J.; Altmann, F.; et al. Arabidopsis thaliana $\beta 1,2$-xylosyltransferase: An unusual glycosyltransferase with the potential to act at multiple stages of the plant $N$-glycosylation pathway. Biochem. J. 2005, 388, 515-525. [CrossRef] [PubMed]

42. Götting, C.; Kuhn, J.; Kleesiek, K. Human xylosyltransferases in health and disease. Cell. Mol. Life Sci. 2007, 64, 1498-1517. [CrossRef] [PubMed]

43. Reilly, M.C.; Aoki, K.; Wang, Z.A.; Skowyra, M.L.; Williams, M.; Tiemeyer, M.; Doering, T.L. A xylosylphosphotransferase of Cryptococcus neoformans acts in protein O-glycan synthesis. J. Biol. Chem. 2011, 286, 26888-26899. [CrossRef] [PubMed]

44. Cottrell, T.R.; Griffith, C.L.; Liu, H.; Nenninger, A.A.; Doering, T.L. The pathogenic fungus Cryptococcus neoformans expresses two functional GDP-mannose transporters with distinct expression patterns and roles in capsule synthesis. Eukaryot. Cell 2007, 6, 776-785. [CrossRef] [PubMed]

45. Wang, Z.A.; Griffith, C.L.; Skowyra, M.L.; Salinas, N.; Williams, M.; Maier, E.J.; Gish, S.R.; Liu, H.; Brent, M.R.; Doering, T.L. Cryptococcus neoformans dual GDP-mannose transporters and their role in biology and virulence. Eukaryot. Cell 2014, 13, 832-842. [CrossRef] [PubMed]

46. Freeze, H.H.; Elbein, A.D. Glycosilation precursors. In Essentials of Glycobiology; Cold Spring Harbor Press: Cold Spring Harbor, NY, USA, 2009; pp. 47-61.

47. Poster, J.B.; Dean, N. The yeast VRG4 gene is required for normal Golgi functions and defines a new family of related genes. J. Biol. Chem. 1996, 271, 3837-3845. [PubMed]

48. Arakawa, K.; Abe, M.; Noda, Y.; Adachi, H.; Yoda, K. Molecular cloning and characterization of a Pichia pastoris ortholog of the yeast Golgi GDP-mannose transporter gene. J. Gen. Appl. Microbiol. 2006, 52, 137-145. [CrossRef] [PubMed] 
49. Carvalho, N.D.; Arentshorst, M.; Weenink, X.O.; Punt, P.J.; van den Hondel, C.A.; Ram, A.F. Functional YFP-tagging of the essential GDP-mannose transporter reveals an important role for the secretion related small GTPase SrgC protein in maintenance of Golgi bodies in Aspergillus niger. Fungal Biol. 2011, 115, $253-264$. [CrossRef] [PubMed]

50. Nishikawa, A.; Poster, J.B.; Jigami, Y.; Dean, N. Molecular and phenotypic analysis of CaVRG4, encoding an essential Golgi apparatus GDP-mannose transporter. J. Bacteriol. 2002, 184, 29-42. [CrossRef] [PubMed]

51. Engel, J.; Schmalhorst, P.S.; Routier, F.H. Biosynthesis of the fungal cell wall polysaccharide galactomannan requires intraluminal GDP-mannose. J. Biol. Chem. 2012, 287, 44418-44424. [CrossRef] [PubMed]

52. Baldwin, T.C.; Handford, M.G.; Yuseff, M.I.; Orellana, A.; Dupree, P. Identification and characterization of GONST1, a golgi-localized GDP-mannose transporter in Arabidopsis. Plant Cell 2001, 13, $2283-2295$. [CrossRef] [PubMed]

53. Handford, M.G.; Sicilia, F.; Brandizzi, F.; Chung, J.H.; Dupree, P. Arabidopsis thaliana expresses multiple Golgi-localised nucleotide-sugar transporters related to GONST1. Mol. Genet. Genom. 2004, 272, 397-410. [CrossRef] [PubMed]

54. Ma, D.; Russell, D.G.; Beverley, S.M.; Turco, S.J. Golgi GDP-mannose uptake requires Leishmania LPG2. A member of a eukaryotic family of putative nucleotide-sugar transporters. J. Biol. Chem. 1997, 272, 3799-3805. [CrossRef] [PubMed]

55. Doering, T.L. A unique alpha-1,3 mannosyltransferase of the pathogenic fungus Cryptococcus neoformans. J. Bacteriol. 1999, 181, 5482-5488. [PubMed]

56. Sommer, U.; Liu, H.; Doering, T.L. An $\alpha$-1,3-mannosyltransferase of Cryptococcus neoformans. J. Biol. Chem. 2003, 278, 47724-47730. [CrossRef] [PubMed]

57. Albuquerque, P.C.; Cordero, R.J.B.; Fonseca, F.L.; da Silva, R.P.; Ramos, C.L.; Miranda, K.R.; Casadevall, A.; Puccia, R.; Nosanchuk, J.D.; Nimrichter, L.; et al. A Paracoccidioides brasiliensis glycan shares serologic and functional properties with cryptococcal glucuronoxylomannan. Fungal Genet. Biol. 2012, 49, $943-954$. [CrossRef] [PubMed]

58. Park, Y.-D.; Shin, S.; Panepinto, J.; Ramos, J.; Qiu, J.; Frases, S.; Albuquerque, P.; Cordero, R.J.B.; Zhang, N.; Himmelreich, U.; et al. A role for LHC1 in higher order structure and complement binding of the Cryptococcus neoformans capsule. PLoS Pathog. 2014, 10, e1004037. [CrossRef] [PubMed]

59. Kobayashi, M.; Shinohara, M.; Sakoh, C.; Kataoka, M.; Shimizu, S. Lactone-ring-cleaving enzyme: Genetic analysis, novel RNA editing, and evolutionary implications. Proc. Natl. Acad. Sci. USA 1998, 95, 12787-12792. [CrossRef] [PubMed]

60. Wang, Y.; Aisen, P.; Casadevall, A. Cryptococcus neoformans melanin and virulence: Mechanism of action. Infect. Immun. 1995, 63, 3131-3136. [PubMed]

61. Van Duin, D.; Casadevall, A.; Nosanchuk, J.D. Melanization of Cryptococcus neoformans and Histoplasma capsulatum reduces their susceptibilities to amphotericin B and caspofungin. Antimicrob. Agents Chemother. 2002, 46, 3394-3400. [CrossRef] [PubMed]

62. Larsson, B.S. Interaction between chemicals and melanin. Pigment Cell Res. 1993, 6, 127-133. [CrossRef] [PubMed]

63. Wang, Y.; Casadevall, A. Susceptibility of melanized and nonmelanized Cryptococcus neoformans to the melanin-binding compounds trifluoperazine and chloroquine. Antimicrob. Agents Chemother. 1996, 40, 541-545. [PubMed]

64. Eilam, Y.; Polacheck, I.; Ben-Gigi, G.; Chernichovsky, D. Activity of phenothiazines against medically important yeasts. Antimicrob. Agents Chemother. 1987, 31, 834-836. [CrossRef] [PubMed]

65. Nosanchuk, J.D.; Ovalle, R.; Casadevall, A. Glyphosate inhibits melanization of Cryptococcus neoformans and prolongs survival of mice after systemic infection. J. Infect. Dis. 2001, 183, 1093-1099. [CrossRef] [PubMed]

66. Inoue, S.; Hasegawa, K.; Ito, S.; Wakamatsu, K.; Fujita, K. Antimelanoma activity of chloroquine, an antimalarial agent with high affinity for melanin. Pigment Cell Res. 1993, 6, 354-358. [CrossRef] [PubMed]

67. Rosas, A.L.; Nosanchuk, J.D.; Casadevall, A. Passive immunization with melanin-binding monoclonal antibodies prolongs survival of mice with lethal Cryptococcus neoformans infection. Infect. Immun. 2001, 69, 3410-3412. [CrossRef] [PubMed]

68. Thurston, C.F. The structure and function of fungal laccases. Microbiology 1994, 140, 19-26. [CrossRef] 
69. Zoccarato, F.; Toscano, P.; Alexandre, A. Dopamine-derived dopaminochrome promotes $\mathrm{H}_{2} \mathrm{O}_{2}$ release at mitochondrial complex I: Stimulation by rotenone, control by $\mathrm{Ca}^{2+}$, and relevance to Parkinson disease. J. Biol. Chem. 2005, 280, 15587-15594. [CrossRef] [PubMed]

70. Liu, L.; Tewari, R.P.; Williamson, P.R. Laccase protects Cryptococcus neoformans from antifungal activity of alveolar macrophages. Infect. Immun. 1999, 67, 6034-6039. [PubMed]

71. Missall, T.A.; Moran, J.M.; Corbett, J.A.; Lodge, J.K. Distinct stress responses of two functional laccases in Cryptococcus neoformans are revealed in the absence of the thiol-specific antioxidant Tsa1. Eukaryot. Cell 2005, 4, 202-208. [CrossRef] [PubMed]

72. Polacheck, I.; Hearing, V.J.; Kwon-Chung, K.J. Biochemical studies of phenoloxidase and utilization of catecholamines in Cryptococcus neoformans. J. Bacteriol. 1982, 150, 1212-1220. [PubMed]

73. Salas, S.D.; Bennett, J.E.; Kwon-Chung, K.J.; Perfect, J.R.; Williamson, P.R. Effect of the laccase gene CNLAC1, on virulence of Cryptococcus neoformans. J. Exp. Med. 1996, 184, 377-386. [CrossRef] [PubMed]

74. Pukkila-Worley, R.; Gerrald, Q.D.; Kraus, P.R.; Boily, M.-J.; Davis, M.J.; Giles, S.S.; Cox, G.M.; Heitman, J.; Alspaugh, J.A. Transcriptional network of multiple capsule and melanin genes governed by the Cryptococcus neoformans cyclic AMP cascade. Eukaryot. Cell 2005, 4, 190-201. [CrossRef] [PubMed]

75. Kronstad, J.; Saikia, S.; Nielson, E.D.; Kretschmer, M.; Jung, W.; Hu, G.; Geddes, J.M.H.; Griffiths, E.J.; Choi, J.; Cadieux, B.; et al. Adaptation of Cryptococcus neoformans to mammalian hosts: Integrated regulation of metabolism and virulence. Eukaryot. Cell 2012, 11, 109-118. [CrossRef] [PubMed]

76. Almeida, F.; Wolf, J.M.; Casadevall, A. Virulence-associated enzymes of Cryptococcus neoformans. Eukaryot. Cell 2015, 14, 1173-1185. [CrossRef] [PubMed]

77. Cox, G.M.; Mukherjee, J.; Cole, G.T.; Casadevall, A.; Perfect, J.R. Urease as a virulence factor in experimental cryptococcosis. Infect. Immun. 2000, 68, 443-448. [CrossRef] [PubMed]

78. Olszewski, M.A.; Noverr, M.C.; Chen, G.-H.; Toews, G.B.; Cox, G.M.; Perfect, J.R.; Huffnagle, G.B. Urease expression by Cryptococcus neoformans promotes microvascular sequestration, thereby enhancing central nervous system invasion. Am. J. Pathol. 2004, 164, 1761-1771. [CrossRef]

79. Casadevall, A. Cryptococci at the brain gate: Break and enter or use a Trojan horse? J. Clin. Investig. 2010, 120, 1389-1392. [CrossRef] [PubMed]

80. Collopy-Junior, I.; Esteves, F.F.; Nimrichter, L.; Rodrigues, M.L.; Alviano, C.S.; Meyer-Fernandes, J.R. An ectophosphatase activity in Cryptococcus neoformans. FEMS Yeast Res. 2006, 6, 1010-1017. [CrossRef] [PubMed]

81. Lev, S.; Crossett, B.; Cha, S.Y.; Desmarini, D.; Li, C.; Chayakulkeeree, M.; Wilson, C.F.; Williamson, P.R.; Sorrell, T.C.; Djordjevic, J.T. Identification of Aph1, a phosphate-regulated, secreted, and vacuolar acid phosphatase in Cryptococcus neoformans. mBio 2014, 5, e01649-14. [CrossRef] [PubMed]

82. Rigden, D.J. The histidine phosphatase superfamily: Structure and function. Biochem. J. 2008, 409, $333-348$. [CrossRef] [PubMed]

83. Chen, S.C.; Wright, L.C.; Santangelo, R.T.; Muller, M.; Moran, V.R.; Kuchel, P.W.; Sorrell, T.C. Identification of extracellular phospholipase B, lysophospholipase, and acyltransferase produced by Cryptococcus neoformans. Infect. Immun. 1997, 65, 405-411. [PubMed]

84. Cox, G.M.; McDade, H.C.; Chen, S.C.; Tucker, S.C.; Gottfredsson, M.; Wright, L.C.; Sorrell, T.C.; Leidich, S.D.; Casadevall, A.; Ghannoum, M.A.; et al. Extracellular phospholipase activity is a virulence factor for Cryptococcus neoformans. Mol. Microbiol. 2001, 39, 166-175. [CrossRef] [PubMed]

85. Noverr, M.C.; Cox, G.M.; Perfect, J.R.; Huffnagle, G.B. Role of PLB1 in pulmonary inflammation and cryptococcal eicosanoid production. Infect. Immun. 2003, 71, 1538-1547. [CrossRef] [PubMed]

86. Santangelo, R.; Zoellner, H.; Sorrell, T.; Wilson, C.; Donald, C.; Djordjevic, J.; Shounan, Y.; Wright, L. Role of extracellular phospholipases and mononuclear phagocytes in dissemination of cryptococcosis in a murine model. Infect. Immun. 2004, 72, 2229-2239. [CrossRef] [PubMed]

87. Siafakas, A.R.; Sorrell, T.C.; Wright, L.C.; Wilson, C.; Larsen, M.; Boadle, R.; Williamson, P.R.; Djordjevic, J.T. Cell wall-linked cryptococcal phospholipase B1 is a source of secreted enzyme and a determinant of cell wall integrity. J. Biol. Chem. 2007, 282, 37508-37514. [CrossRef] [PubMed]

88. Yang, P.; Du, H.; Hoffman, C.S.; Marcus, S. The phospholipase B homolog Plb1 is a mediator of osmotic stress response and of nutrient-dependent repression of sexual differentiation in the fission yeast Schizosaccharomyces pombe. Mol. Genet. Genom. 2003, 269, 116-125. 
89. Obando, D.; Pantarat, N.; Handke, R.; Koda, Y.; Widmer, F.; Djordjevic, J.T.; Ellis, D.H.; Sorrell, T.C.; Jolliffe, K.A. Synthesis, antifungal, haemolytic and cytotoxic activities of a series of bis(alkylpyridinium)alkanes. Bioorg. Med. Chem. 2009, 17, 6329-6339. [CrossRef] [PubMed]

90. Djordjevic, J.T. Role of phospholipases in fungal fitness, pathogenicity, and drug development-Lessons from Cryptococcus neoformans. Front. Microbiol. 2010, 1, 125. [CrossRef] [PubMed]

91. Chayakulkeeree, M.; Sorrell, T.C.; Siafakas, A.R.; Wilson, C.F.; Pantarat, N.; Gerik, K.J.; Boadle, R.; Djordjevic, J.T. Role and mechanism of phosphatidylinositol-specific phospholipase $C$ in survival and virulence of Cryptococcus neoformans. Mol. Microbiol. 2008, 69, 809-826. [PubMed]

92. Lev, S.; Desmarini, D.; Li, C.; Chayakulkeeree, M.; Traven, A.; Sorrell, T.C.; Djordjevic, J.T. Phospholipase C of Cryptococcus neoformans regulates homeostasis and virulence by providing inositol trisphosphate as a substrate for Arg1 kinase. Infect. Immun. 2013, 81, 1245-1255. [CrossRef] [PubMed]

93. Flick, J.S.; Thorner, J. Genetic and biochemical characterization of a phosphatidylinositol-specific phospholipase C in Saccharomyces cerevisiae. Mol. Cell. Biol. 1993, 13, 5861-5876. [CrossRef] [PubMed]

94. Bennett, D.E.; McCreary, C.E.; Coleman, D.C. Genetic characterization of a phospholipase C gene from Candida albicans: Presence of homologous sequences in Candida species other than Candida albicans. Microbiol. Read. Engl. 1998, 144, 55-72. [CrossRef] [PubMed]

95. Fridovich, I. Superoxide radical and superoxide dismutases. Annu. Rev. Biochem. 1995, 64, 97-112. [CrossRef] [PubMed]

96. Cox, G.M.; Harrison, T.S.; McDade, H.C.; Taborda, C.P.; Heinrich, G.; Casadevall, A.; Perfect, J.R. Superoxide dismutase influences the virulence of Cryptococcus neoformans by affecting growth within macrophages. Infect. Immun. 2003, 71, 173-180. [CrossRef] [PubMed]

97. Hamilton, A.J.; Holdom, M.D. Biochemical comparison of the $\mathrm{Cu}, \mathrm{Zn}$ superoxide dismutases of Cryptococcus neoformans var. neoformans and Cryptococcus neoformans var. gattii. Infect. Immun. 1997, 65, 488-494. [PubMed]

98. Narasipura, S.D.; Ault, J.G.; Behr, M.J.; Chaturvedi, V.; Chaturvedi, S. Characterization of Cu,Zn superoxide dismutase (SOD1) gene knock-out mutant of Cryptococcus neoformans var. gattii: Role in biology and virulence. Mol. Microbiol. 2003, 47, 1681-1694. [CrossRef] [PubMed]

99. Narasipura, S.D.; Chaturvedi, V.; Chaturvedi, S. Characterization of Cryptococcus neoformans variety gattii SOD2 reveals distinct roles of the two superoxide dismutases in fungal biology and virulence. Mol. Microbiol. 2005, 55, 1782-1800. [CrossRef] [PubMed]

100. Jacobson, E.S.; Jenkins, N.D.; Todd, J.M. Relationship between superoxide dismutase and melanin in a pathogenic fungus. Infect. Immun. 1994, 62, 4085-4086. [PubMed]

101. Giles, S.S.; Batinic-Haberle, I.; Perfect, J.R.; Cox, G.M. Cryptococcus neoformans mitochondrial superoxide dismutase: An essential link between antioxidant function and high-temperature growth. Eukaryot. Cell 2005, 4, 46-54. [CrossRef] [PubMed]

102. Rodrigues, M.L.; Nakayasu, E.S.; Oliveira, D.L.; Nimrichter, L.; Nosanchuk, J.D.; Almeida, I.C.; Casadevall, A. Extracellular vesicles produced by Cryptococcus neoformans contain protein components associated with virulence. Eukaryot. Cell 2008, 7, 58-67. [CrossRef] [PubMed]

103. Schekman, R.W. Regulation of membrane traffic in the secretory pathway. Harvey Lect. 1994, 90, 41-57. [PubMed]

104. Kmetzsch, L.; Joffe, L.S.; Staats, C.C.; de Oliveira, D.L.; Fonseca, F.L.; Cordero, R.J.B.; Casadevall, A.; Nimrichter, L.; Schrank, A.; Vainstein, M.H.; et al. Role for Golgi reassembly and stacking protein (GRASP) in polysaccharide secretion and fungal virulence. Mol. Microbiol. 2011, 81, 206-218. [CrossRef] [PubMed]

105. Rizzo, J.; Oliveira, D.L.; Joffe, L.S.; Hu, G.; Gazos-Lopes, F.; Fonseca, F.L.; Almeida, I.C.; Frases, S.; Kronstad, J.W.; Rodrigues, M.L. Role of the Apt1 protein in polysaccharide secretion by Cryptococcus neoformans. Eukaryot. Cell 2014, 13, 715-726. [CrossRef] [PubMed]

106. Godinho, R.M.; Crestani, J.; Kmetzsch, L.; Araujo, G.; Frases, S.; Staats, C.C.; Schrank, A.; Vainstein, M.H.; Rodrigues, M.L. The vacuolar-sorting protein Snf7 is required for export of virulence determinants in members of the Cryptococcus neoformans complex. Sci. Rep. 2014, 4, 6198. [CrossRef] [PubMed]

107. Xu, X.; Zhao, Y.; Kirkman, E.; Lin, X. Secreted Acb1 contributes to the yeast-to-hypha transition in Cryptococcus neoformans. Appl. Environ. Microbiol. 2016, 82, 1069-1079. [CrossRef] [PubMed] 
108. Mendes, L.F.S.; Garcia, A.F.; Kumagai, P.S.; de Morais, F.R.; Melo, F.A.; Kmetzsch, L.; Vainstein, M.H.; Rodrigues, M.L.; Costa-Filho, A.J. New structural insights into Golgi Reassembly and Stacking Protein (GRASP) in solution. Sci. Rep. 2016, 6, 29976. [CrossRef] [PubMed]

109. Hu, G.; Caza, M.; Cadieux, B.; Bakkeren, E.; Do, E.; Jung, W.H.; Kronstad, J.W. The endosomal sorting complex required for transport machinery influences haem uptake and capsule elaboration in Cryptococcus neoformans. Mol. Microbiol. 2015, 96, 973-992. [CrossRef] [PubMed]

110. Huang, W.; Liao, G.; Baker, G.M.; Wang, Y.; Lau, R.; Paderu, P.; Perlin, D.S.; Xue, C. Lipid Flippase Subunit Cdc50 Mediates Drug Resistance and Virulence in Cryptococcus Neoformans. mBio 2016, 7. [CrossRef] [PubMed]

111. Del Poeta, M.; Nimrichter, L.; Rodrigues, M.L.; Luberto, C. Synthesis and biological properties of fungal glucosylceramide. PLoS Pathog. 2014, 10, e1003832. [CrossRef] [PubMed]

112. Rodrigues, M.L.; Travassos, L.R.; Miranda, K.R.; Franzen, A.J.; Rozental, S.; de Souza, W.; Alviano, C.S.; Barreto-Bergter, E. Human antibodies against a purified glucosylceramide from Cryptococcus neoformans inhibit cell budding and fungal growth. Infect. Immun. 2000, 68, 7049-7060. [CrossRef] [PubMed]

113. Rodrigues, M.L.; Shi, L.; Barreto-Bergter, E.; Nimrichter, L.; Farias, S.E.; Rodrigues, E.G.; Travassos, L.R.; Nosanchuk, J.D. Monoclonal antibody to fungal glucosylceramide protects mice against lethal Cryptococcus neoformans infection. Clin. Vaccine Immunol. 2007, 14, 1372-1376. [CrossRef] [PubMed]

114. Rittershaus, P.C.; Kechichian, T.B.; Allegood, J.C.; Merrill, A.H.; Hennig, M.; Luberto, C.; Del Poeta, M. Glucosylceramide synthase is an essential regulator of pathogenicity of Cryptococcus neoformans. J. Clin. Investig. 2006, 116, 1651-1659. [CrossRef] [PubMed]

115. Rollin-Pinheiro, R.; Singh, A.; Barreto-Bergter, E.; Del Poeta, M. Sphingolipids as targets for treatment of fungal infections. Future Med. Chem. 2016, 8, 1469-1484. [CrossRef] [PubMed]

116. Mor, V.; Rella, A.; Farnoud, A.M.; Singh, A.; Munshi, M.; Bryan, A.; Naseem, S.; Konopka, J.B.; Ojima, I.; Bullesbach, E.; et al. Identification of a new class of antifungals targeting the synthesis of fungal sphingolipids. mBio 2015, 6, e00647. [CrossRef] [PubMed]

117. Burnie, J.P.; Carter, T.L.; Hodgetts, S.J.; Matthews, R.C. Fungal heat-shock proteins in human disease. FEMS Microbiol. Rev. 2006, 30, 53-88. [CrossRef] [PubMed]

118. Cordeiro, R.; Evangelista, A.J.; Serpa, R.; Marques, F.J.; Melo, C.V.; Oliveira, J.S.; Franco, J.; Alencar, L.P.; Bandeira, T.; Brilhante, R.S.N.; et al. Inhibition of heat-shock protein 90 enhances the susceptibility to antifungals and reduces the virulence of Cryptococcus neoformans/Cryptococcus gattii species complex. Microbiol. Read. Engl. 2016, 162, 309-317. [CrossRef] [PubMed]

119. Nooney, L.; Matthews, R.C.; Burnie, J.P. Evaluation of Mycograb, amphotericin B, caspofungin, and fluconazole in combination against Cryptococcus neoformans by checkerboard and time-kill methodologies. Diagn. Microbiol. Infect. Dis. 2005, 51, 19-29. [CrossRef] [PubMed]

120. Cruz, M.C.; Sia, R.A.; Olson, M.; Cox, G.M.; Heitman, J. Comparison of the roles of calcineurin in physiology and virulence in serotype D and serotype A strains of Cryptococcus neoformans. Infect. Immun. 2000, 68, 982-985. [CrossRef] [PubMed]

121. Steinbach, W.J.; Reedy, J.L.; Cramer, R.A.; Perfect, J.R.; Heitman, J. Harnessing calcineurin as a novel anti-infective agent against invasive fungal infections. Nat. Rev. Microbiol. 2007, 5, 418-430. [CrossRef] [PubMed]

122. Odom, A.; Muir, S.; Lim, E.; Toffaletti, D.L.; Perfect, J.; Heitman, J. Calcineurin is required for virulence of Cryptococcus neoformans. EMBO J. 1997, 16, 2576-2589. [CrossRef] [PubMed]

123. Singh, N.; Alexander, B.D.; Lortholary, O.; Dromer, F.; Gupta, K.L.; John, G.T.; del Busto, R.; Klintmalm, G.B.; Somani, J.; Lyon, G.M.; et al. Cryptococcus neoformans in organ transplant recipients: Impact of calcineurin-inhibitor agents on mortality. J. Infect. Dis. 2007, 195, 756-764. [CrossRef] [PubMed]

124. Bastidas, R.J.; Reedy, J.L.; Morales-Johansson, H.; Heitman, J.; Cardenas, M.E. Signaling cascades as drug targets in model and pathogenic fungi. Curr. Opin. Investig. Drugs Lond. Engl. 2008, 9, 856-864.

125. Cruz, M.C.; Del Poeta, M.; Wang, P.; Wenger, R.; Zenke, G.; Quesniaux, V.F.; Movva, N.R.; Perfect, J.R.; Cardenas, M.E.; Heitman, J. Immunosuppressive and nonimmunosuppressive cyclosporine analogs are toxic to the opportunistic fungal pathogen Cryptococcus neoformans via cyclophilin-dependent inhibition of calcineurin. Antimicrob. Agents Chemother. 2000, 44, 143-149. [CrossRef] [PubMed] 
126. Lodge, J.K.; Jackson-Machelski, E.; Toffaletti, D.L.; Perfect, J.R.; Gordon, J.I. Targeted gene replacement demonstrates that myristoyl-CoA: Protein $N$-myristoyltransferase is essential for viability of Cryptococcus neoformans. Proc. Natl. Acad. Sci. USA 1994, 91, 12008-12012. [CrossRef] [PubMed]

127. Panethymitaki, C.; Bowyer, P.W.; Price, H.P.; Leatherbarrow, R.J.; Brown, K.A.; Smith, D.F. Characterization and selective inhibition of myristoyl-CoA:protein $N$-myristoyltransferase from Trypanosoma brucei and Leishmania major. Biochem. J. 2006, 396, 277-285. [CrossRef] [PubMed]

128. Langner, C.A.; Lodge, J.K.; Travis, S.J.; Caldwell, J.E.; Lu, T.; Li, Q.; Bryant, M.L.; Devadas, B.; Gokel, G.W.; Kobayashi, G.S. 4-oxatetradecanoic acid is fungicidal for Cryptococcus neoformans and inhibits replication of human immunodeficiency virus I. J. Biol. Chem. 1992, 267, 17159-17169. [PubMed]

129. Georgopapadakou, N.H. Antifungals targeted to protein modification: Focus on protein N-myristoyltransferase. Expert Opin. Investig. Drugs 2002, 11, 1117-1125. [CrossRef] [PubMed]

130. Bowyer, P.W.; Tate, E.W.; Leatherbarrow, R.J.; Holder, A.A.; Smith, D.F.; Brown, K.A. N-myristoyltransferase: A prospective drug target for protozoan parasites. ChemMedChem 2008, 3, 402-408. [CrossRef] [PubMed]

131. Zhao, C.; Ma, S. Recent advances in the discovery of $N$-myristoyltransferase inhibitors. ChemMedChem 2014, 9, 2425-2437. [CrossRef] [PubMed]

132. Kishore, N.S.; Wood, D.C.; Mehta, P.P.; Wade, A.C.; Lu, T.; Gokel, G.W.; Gordon, J.I. Comparison of the acyl chain specificities of human myristoyl-CoA synthetase and human myristoyl-CoA:protein N-myristoyltransferase. J. Biol. Chem. 1993, 268, 4889-4902. [PubMed]

133. Gunaratne, R.S.; Sajid, M.; Ling, I.T.; Tripathi, R.; Pachebat, J.A.; Holder, A.A. Characterization of $\mathrm{N}$-myristoyltransferase from Plasmodium falciparum. Biochem. J. 2000, 348, 459-463. [CrossRef] [PubMed]

(C) 2016 by the authors; licensee MDPI, Basel, Switzerland. This article is an open access article distributed under the terms and conditions of the Creative Commons Attribution (CC-BY) license (http:/ / creativecommons.org/licenses/by/4.0/). 